\title{
Relationship between Wood Traits and Sound Frequency at Different Pitch Levels of Talking Drums (Gangan) Manufactured from Aningeria robusta Wood
}

\author{
K.O. Olaoye | ORCID 0000-0002-9808-2299 \\ Federal College of Forestry, Forestry Research Institute of Nigeria, Ibadan, \\ Nigeria \\ snipeskay@gmail.com
}

\author{
A.O. Oluwadare \\ Department of Forest Production and Products, Faculty of Renewable \\ Natural Resources, University of Ibadan, Ibadan, Nigeria \\ aoluwada@gmail.com
}

\begin{abstract}
Wood is a unique material for making musical instruments and is used to make West African talking drums, whose pitch can be regulated depending upon how the player strikes the head of drum and changes its tension. Additionally, talking drum manufacturers have certain wood preferences, and in the absence of preferred species, they use supposedly unsuitable woods. Therefore, there is a need to examine wood traits in relation to the pitch of a talking drum. This study was designed to determine the existing relationship between selected wood traits and the frequency of talking drums made from A. robusta wood. Three A. robusta trees were obtained from Onigambari Forest Reserve. From each tree, three bolts of $50 \mathrm{~cm}$ in length were obtained from the base, middle, and top of the tree to determine selected properties (moisture content (MC), wood basic density (WBD), modulus of elasticity (MOE), modulus of rupture (MOR), and manufacturing of talking drums). A spectrum analyzer was used to analyze the sound frequency of the talking drums at three pitch levels (high, medium, low). A completely randomized block design was used and the data obtained was analyzed using descriptive statistics, ANOVA, and correlation analyses at $\alpha_{0.05}$. Sound frequency was not significant along sampling height, but was significant at pitch levels. Additionally,
\end{abstract}


the correlation analysis between wood traits and sound frequency was not significant. Thus, wood cannot be recommended for talking drums' optimal acoustic performance based on wood traits alone.

\section{Keywords}

talking drum - sound frequency - pitch - Anningeria robusta - wood trait

\section{Introduction}

Africa is the second largest continent in the world, with about one thousand indigenous languages and other foreign languages, and it is a place rich with diverse cultural heritage (Stone 1998), such as its music and musical instruments. One African musical instrument is the talking drum, which is classified by its different shapes and sizes into types, such as Gudugudu, Iya ilu, Dandan, Gangan, Omele gangan, and it has been traced back to the early history of the Yoruba (Abel 1998).

Talking drums are West African drums whose pitch can be regulated depending upon how the player strikes the head of drum and changes its tension (Akere 1995). It is shaped like an hour glass with two faces that are vertically opposite each other with leather string, while the shell is made from carved wood, the main material used in talking drum construction (Wikipedia, 2019). The wood that is usually used for carving these drums are Afzelia bipindensis (Apa), Tectina grandis (Teak), Cordia millennia (Omo), and Gmelina arborea, which are all hardwood species.

Wood is a unique material in the construction of musical instruments and in other acoustic applications because it can produce sound (by direct striking) and can amplify or absorb sound waves originating from other bodies. In spite of recent advances in material science, wood remains the preferred construction material for musical instruments worldwide because of some of its distinguishing features, such as its light weight and intermediate quality factor that are easily noticeable when compared with plastic or metal (Yoshikawa and Waltham 2014). However, an important area of research in wood utilization that has so far been ignored is the production of musical instruments.

Cordia millenii has been the preferred species of wood for manufacturers of talking drums in Nigeria, based on the inherited indigenous knowledge that it has been the standard drum-making wood species for many years without any attempts at domestication. However, the species has become scarce due to its 
multiple uses by the carving and other wood-based industries. Additionally, Femi (2019) confirms an increase in the popularity and advancement of African music today due to the utilization of talking drums, which have immensely increased the international popularity of Nigerian culture and its entertainment industry. Thus, the popularity of talking drums added to the mounting pressure on the already threatened species.

Consequently, the shortage of this species has forced the carving industry to employ many unsuitable species for the manufacture of talking drums that eventually render unsatisfactory services to users. The unsuitability of these alternative wood species may be greatly due to the poor relationship between the characteristics of the wood and the respective acoustic properties of the talking drum.

In the quest for finding alternative wood species for making talking drums, Olaoye et al. (2016) endeavored to study selected physico-mechanical properties of A. robusta wood for the purpose of finding wood with traits similar to the preferred species of wood for making talking drums. However, the study did not look into the fiber traits of the wood nor establish a relationship between these properties and the acoustic properties of the talking drum.

On the other hand, one of the major acoustic properties of a musical instrument is its pitch. The uniqueness of a talking drum is its capacity to be regulated to mimic the tone and prosody of human speech through changes in pitch. Therefore, it is pertinent to consider different pitch levels to be able to establish a relationship between wood traits and the pitch of the sound of a talking drum.

Although, scholars such as Albert et al. (2002) and Bremaud (2012) have established a relationship between a selected wood trait and the acoustic properties of wood, little or no information is available about the influence of this relationship on the musical instrument itself.

There is therefore a need to research lesser-known wood species for the manufacture of talking drums and to establish a possible relationship between wood traits and the drum's pitch. Research into lesser-known wood species, like Aningeria robusta wood from Nigeria, to determine their suitability for making talking drums and to establish a possible relationship between wood traits and the pitch of the drum will not only help to reduce pressure on the scarce yet popular Cordia millenii species, but also contribute to the social, cultural, and economic lifestyle of the population of Nigeria.

Furthermore, it should be noted that pitch is positively correlated with sound frequency (Plack et al. 2005). As such, sound frequency is the measure of pitch. In addition, Tsoumis (1991) stated that the pitch produced depends on the frequency of vibration, which is affected by the dimensions, density, 
moisture content, and modulus of elasticity of the wood. Smaller dimensions, lower moisture content, and higher density and elasticity produce sounds of a higher pitch.

Aningeria robusta belongs to the family Sapotaceae, a hardwood. It is called "agengre" in Cote d'Ivoire, "landosan" in Nigeria, and "osan" in Uganda (TRADA 1979, cited in Ajala and Ogunsanwo (2011)), "mukali" in Angola, "mukangu" in Kenya (Chudnoff 1980, cited in Ajala and Ogunsanwo 2011), and "asafonia" in Ghana (Okai 2003).

The aim of this study was to determine the relationship between wood traits and sound frequency at different pitch levels for talking drums manufactured from Aningeria robusta, with the view of exploring the suitability of this type of wood for manufacturing talking drums and providing relevant information.

\section{$2 \quad$ Materials and Methods}

\subsection{Sample Collection and Preparation}

Three trees of Aningeria robusta with at least $25 \mathrm{~cm}$ DBH obtained from Onigambari Forest Reserve were selected. Bolts $50 \mathrm{~cm}$ in length were collected at the base, middle, and top of each tree to determine the physical and mechanical properties of the species as well as its viability for the manufacturing of talking drums.

The wood samples were processed using a circular machine and planning machine to $20 \times 20 \times 300 \mathrm{~mm}$ for modulus of elasticity and modulus of rupture (mechanical property), $20 \times 20 \times 20 \mathrm{~mm}$ for fiber characteristics, and $20 \times 20 \times$ 6o mm for wood density and moisture content according to ASTM 1991.

\subsection{Determination of Wood Traits}

2.2.1 Moisture Content

The samples were weighed when wet (original weight), and then dried to a constant weight at $103 \pm 2{ }^{\circ} \mathrm{C}$ in an oven for 24 hours, after which they were re-weighed. The wood samples' reduction in weight during the drying process was noted. The loss in weight as a percentage of the samples' weight after drying was calculated using the formula below:

$$
\mathrm{MC}=\frac{\mathrm{ww}-\mathrm{ow}}{\mathrm{ow}} \times 100
$$

where $\mathrm{MC}=$ moisture content, $\mathrm{ww}=$ wet weight and ow oven dry weight. 


\subsubsection{Wood Density}

The $20 \times 20 \times 60 \mathrm{~mm}$ wood samples collected were oven dried to a constant weight at $103 \pm 2^{\circ} \mathrm{C}$ for 24 hours, and their weight recorded afterward. The volume of samples at green weight was recorded and the following formula was adopted for the calculation of wood density.

$$
D=\frac{m}{v}\left(\mathrm{~kg} / \mathrm{m}^{3}\right)
$$

where $D=$ density, $m=$ oven-dried mass and $v=$ green volume.

\subsubsection{Modulus of Rupture (MOR)}

Analyzing this characteristic involved the use of a standard test specimen (10 $\times 10 \times 300 \mathrm{~mm}$ ) in a universal testing machine. The test sample was prepared in such a way that growth rings will be made parallel to one edge. Load was applied at the rate of $0.2 \mathrm{~mm} / \mathrm{sec}$ with the growth rings parallel to the direction of loading, that is, the specimen was loaded on the radial face. From the graph generated by the universal testing machine, the peak and breaking forces were recorded; hence, "MOR" was calculated as thus:

$$
\text { MOR }=\frac{3 P L}{2 b d 2 \rightleftarrows}(\mathrm{N} / \mathrm{mm} 2)
$$

where MOR = modulus of rupture, $P=$ load needed for failure, $L=$ span of the material between support (length), $b=$ width of the material and $d=$ thickness of the material.

\subsubsection{Modulus of Elasticity}

The graph generated from the universal testing machine was used to obtain the force needed to reach the wood's elastic limit and its displacement. The modulus of elasticity was calculated from these values. Thus,

$$
M O E=\frac{P L^{3}}{4 \Delta b d^{3}}\left(N / \mathrm{mm}^{2}\right)
$$

where $P=\operatorname{load}(\mathrm{N}), L=\operatorname{span} /$ length $(\mathrm{mm}), B=$ width $(\mathrm{mm}), D=\operatorname{depth}(\mathrm{mm})$ and $\Delta=$ the displacement at beam center at proportional load.

2.2.5 Speed/Velocity of Sound

$$
c=\sqrt{\frac{E}{\rho}}
$$

where $c=$ speed of sound, $E=$ modulus of elasticity and $\rho=$ density. 
TABLE 1 Mean values of selected wood traits determined for A. robusta

\begin{tabular}{|c|c|c|c|c|}
\hline & Tree 1 & Tree 2 & Tree 3 & Mean \\
\hline \multicolumn{5}{|l|}{ MC (\%) } \\
\hline Top & 58.02 & 62.65 & 65.12 & $61.93 \pm 2.08$ \\
\hline Middle & 38.79 & 48.44 & 57.65 & $48.29 \pm 5.44$ \\
\hline Base & 65.88 & 48.49 & $54 \cdot 77$ & $5^{6.38} \pm 5.08$ \\
\hline Mean & $513 \pm 8.04$ & $53.19 \pm 4.72$ & $59.18 \pm 3.08$ & $55 \cdot 54 \pm 2.98$ \\
\hline \multicolumn{5}{|c|}{ Wood density $\left(\mathrm{kg} / \mathrm{m}^{3}\right)$} \\
\hline Top & 380.42 & $407 \cdot 5$ & $434 \cdot 5^{\circ}$ & $407.47 \pm 15.61$ \\
\hline Middle & 361.67 & 517.67 & $45^{2.92}$ & $444.08 \pm 45.24$ \\
\hline Base & 412.25 & 515.25 & 381.92 & $436.472 \pm 40.35$ \\
\hline Mean & $384 \cdot 77 \pm 14 \cdot 76$ & $480.14 \pm 36.32$ & $423.11 \pm 21.2$ & $429 \cdot 34 \pm 18.91$ \\
\hline \multicolumn{5}{|c|}{$\operatorname{MOR}\left(\mathrm{N} / \mathrm{mm}^{2}\right)$} \\
\hline Top & 122.1 & $129 \cdot 5^{1}$ & $129 \cdot 5^{6}$ & $127.06 \pm 2.47$ \\
\hline Middle & 95.04 & 116.33 & 145 & $118.79 \pm 14.47$ \\
\hline Base & 116.73 & 136.87 & 124.08 & $125.893 \pm 5.88$ \\
\hline Mean & $111.29 \pm 8.27$ & $127 \cdot 57 \pm 6.0$ & $132.88 \pm 6.26$ & $123.91 \pm 4.74$ \\
\hline \multicolumn{5}{|c|}{$\operatorname{MOE}\left(\mathrm{N} / \mathrm{mm}^{2}\right)$} \\
\hline Top & 5807.8 & $6435 \cdot 92$ & $66 \circ 9 \cdot 44$ & $6284.39 \pm 243 \cdot 5^{\circ}$ \\
\hline Middle & 5754.87 & 5576.14 & 5660.49 & $5663.83 \pm 51.62$ \\
\hline Base & $6862.5^{2}$ & 3176.22 & 7008.62 & $5682.45 \pm 1253.82$ \\
\hline Mean & $6141.73 \pm 36 \circ .71$ & $5062.76 \pm 975 \cdot 37$ & $6426.18 \pm 399.81$ & $5^{876.89} \pm 3^{82.82}$ \\
\hline \multicolumn{5}{|c|}{ Speed $(\mathrm{m} / \mathrm{s})$} \\
\hline Top & 3907.29 & 3974.12 & 3900.2 & $3927.2 \pm 23.54$ \\
\hline Middle & 3988.99 & 3282.02 & 4363.87 & $3591.63 \pm 208.74$ \\
\hline Base & 4080.01 & 2482.82 & 4283.83 & $3615 \cdot 55 \pm 569 \cdot 41$ \\
\hline Mean & $3992.1 \pm 49.88$ & $3246.32 \pm 430.87$ & $3895 \cdot 97 \pm 225.16$ & $3711.46 \pm 183.35$ \\
\hline \multicolumn{5}{|l|}{$Z\left(\mathrm{~kg} / \mathrm{m}^{2} \mathrm{~s}\right)$} \\
\hline Top & 1486398 & 1619454 & 1694637 & $1600163 \pm 60882.23$ \\
\hline Middle & 1442685 & 1698992 & 1586961 & $1576213 \pm 74184 \cdot 56$ \\
\hline Base & 1681984 & 1279273 & 1636066 & $1532441 \pm 127276.2$ \\
\hline Mean & $1537022 \pm 73171.17$ & $1532573 \pm 128714.5$ & $1639221 \pm 31123.33$ & $15696 \circ 6 \pm 47017 \cdot 33$ \\
\hline
\end{tabular}

2.2.6 Impedance

$z=c \rho \quad$ (Wegst 20o6)

\subsection{Fiber Characteristics}

For the determination of the fiber dimensions, small slivers were obtained at each of the different sampling heights. The slivers were placed in an equal volume (1:1) of $30 \%$ hydrogen peroxide and $10 \%$ glacial acetic acid, boiled until soft, and bleached white (Franklin 1945). The slivers were then washed, placed in $30 \mathrm{ml}$ test tubes with $20 \mathrm{ml}$ of distilled water, and shaken vigorously to separate the fiber bundles into individual fibers. The macerated fiber suspension 
TABLE 1 Mean values of selected wood traits determined for A. robusta (cont.)

\begin{tabular}{|c|c|c|c|c|}
\hline & Tree 1 & Tree 2 & Tree 3 & Mean \\
\hline \multicolumn{5}{|l|}{$\mathrm{FL}(\mathrm{mm})$} \\
\hline Top & 1.73 & 1.37 & $1.5^{1}$ & $1.54 \pm 0.10$ \\
\hline Base & 2.04 & 1.34 & $1.5^{1}$ & $1.63 \pm 0.21$ \\
\hline \multirow[t]{2}{*}{ Mean } & 1.44 & 1.43 & 1.54 & $1.47 \pm 0.35$ \\
\hline & $1.74 \pm 0.17$ & $1.3^{8} \pm 0.03$ & $1.5^{2} \pm 0.01$ & $1.55 \pm 0.10$ \\
\hline \multicolumn{5}{|l|}{$\mathrm{FD}(\mu \mathrm{m})$} \\
\hline Top & 11.83 & 10.67 & 11.48 & $11.33 \pm 0.34$ \\
\hline Middle & 12.21 & 10.99 & 12.43 & $11.88 \pm 0.44$ \\
\hline Base & 12.64 & 11.41 & 11.73 & $11.93 \pm 0.37$ \\
\hline Mean & $12.23 \pm 0.23$ & $11.02 \pm 0.21$ & $11.88 \pm 0.28$ & $11.71 \pm 0.36$ \\
\hline \multicolumn{5}{|l|}{$\mathrm{LW}(\mu \mathrm{m})$} \\
\hline Top & 10.13 & 8.16 & 10.45 & $9 \cdot 5^{8} \pm 0.73$ \\
\hline Middle & 8.43 & 6.67 & 9.60 & $8.23 \pm 0.85$ \\
\hline Base & 9.12 & 8.00 & 8.59 & $8.57 \pm 0.32$ \\
\hline Mean & $9.23 \pm 0.49$ & $7.61 \pm 0.57$ & $9.55 \pm 0.54$ & $8.79 \pm 0.60$ \\
\hline \multicolumn{5}{|l|}{ CWT $(\mu \mathrm{m})$} \\
\hline Top & 0.85 & 1.25 & 0.56 & $0.89 \pm 0.20$ \\
\hline Middle & 1.89 & 2.16 & 1.41 & $1.82 \pm 0.22$ \\
\hline Base & 1.76 & 1.71 & 1.57 & $1.68 \pm 0.06$ \\
\hline Mean & $1.50 \pm 0.33$ & $1.71 \pm 0.26$ & $1.18 \pm 0.31$ & $1.46 \pm 0.15$ \\
\hline
\end{tabular}

MOR, modulus of rupture; MOE, modulus of elasticity; $Z$, impedance; FL, fiber length; FD, fiber diameter; CWT, cell wall thickness.

was carefully aligned on a slide using a rubber teat. The resulting image on a Rheichert visopan microscope screen was measured for fiber length, diameter, lumen width, and cell wall thickness, and were calculated using equation 7 :

$$
\mathrm{CWT}=\frac{\mathrm{FD}-\mathrm{LW}}{2}
$$

Where FD = fiber diameter and $\mathrm{LW}=$ lumen width.

\subsection{Sound Frequency Test}

The talking drums produced were taken to the musical studio of the Department of Music, The Polytechnic, Ibadan, Nigeria for testing. A professional talking drummer made several strikes on the talking drum for 8 seconds while sounds generated and time taken were recorded, after which this data was analyzed using spectrum analyzer to obtain its sound frequencies. The sound frequencies, which are also a measure of the pitch of a sound, were categorized into high, medium, and low frequency levels. 


\subsection{Experimental Design}

The design was comprised of three treatments (top, middle, and base) with three replicates in a completely randomized block design, and significance difference was tested at a $5 \%$ probability level. The variables were analyzed using descriptive analysis of variance (ANOVA) and correlation statistics.

\section{$3 \quad$ Results and Discussion}

\subsection{Selected Wood Traits Determined}

Table 1 shows the mean value of selected wood traits at different sampling heights and among trees.

\subsubsection{Moisture Content}

The base wood of tree 1 had the highest moisture content at $65.88 \%$, and the lowest moisture content $(48.44 \%)$ was obtained from the middle wood of tree 2. The moisture content for $A$. robusta was $55 \cdot 54 \pm 2.98 \%$.

\subsubsection{Wood Density}

Mean wood density for the middle wood of tree 1 was the lowest $(361.67 \mathrm{~kg} /$ $\left.\mathrm{m}^{3}\right)$, and the highest was the middle wood of tree $2\left(517.67 \mathrm{~kg} / \mathrm{m}^{3}\right)$. The wood density for $A$. robusta was $\left(429.34 \pm 18.91 \mathrm{~kg} / \mathrm{m}^{3}\right)$.

\subsubsection{MOR and MOE}

The middle wood of tree 3 had the highest modulus of rupture $\left(145 \mathrm{~N} / \mathrm{mm}^{2}\right)$, and the lowest MOR was the middle wood of tree $1\left(95.04 \mathrm{~N} / \mathrm{mm}^{2}\right)$. The MOR for A. robusta was $123.91 \pm 4.74 \mathrm{~N} / \mathrm{mm}^{2}$, while the mean modulus of elasticity for the base wood of tree $3\left(7008.62 \mathrm{~N} / \mathrm{mm}^{2}\right)$ had the highest modulus of elasticity value and lowest was from the base wood of tree $2\left(3176.22 \mathrm{~N} / \mathrm{mm}^{2}\right)$. The MOE for A. robusta was $5876.89 \pm 382.82 \mathrm{~N} / \mathrm{mm}^{2}$.

\subsubsection{Speed of Sound and Acoustic Impedance}

The speed of sound was highest in the middle wood of tree $3(4363.87 \mathrm{~m} / \mathrm{s})$ and lowest in the base wood of tree $2(2482.82 \mathrm{~m} / \mathrm{s})$. The mean speed of sound in $A$. robusta wood was $3711.46 \pm 183.35 \mathrm{~m} / \mathrm{s}$. Meanwhile, the middle wood of tree 2 had the highest acoustic impedance (1 $\left.698992 \mathrm{~kg} / \mathrm{m}^{2} \mathrm{~s}\right)$, while the lowest acoustic impedance was in the base wood of tree $2\left(1279273 \mathrm{~kg} / \mathrm{m}^{2} \mathrm{~s}\right)$. The mean acoustic impedance for $A$. robusta was $1569606 \pm 47071.33 \mathrm{~kg} / \mathrm{m}^{2} \mathrm{~s}$. 


\subsubsection{Fiber Characteristics}

The mean fiber length, fiber diameter, lumen width, and cell wall thickness were $1.55 \pm 0.10 \mathrm{~mm}, 11.71 \pm 0.36 \mu \mathrm{m}, 8.79 \pm 0.60 \mu \mathrm{m}$, and $1.46 \pm 0.15 \mu \mathrm{m}$, respectively.

\subsection{Sound Frequency Determined}

Figure 1 shows the manufactured talking drums while Figure 2 shows the sound frequency in respect to pitch obtained from the talking drum produced from top, middle, and base of $A$. robusta trees. Middle wood produced the highest frequency $(331 \pm 86.31 \mathrm{~Hz})$ at its highest pitch level, while the lowest frequency ( $50 \pm 11.26 \mathrm{~Hz}$ ) was obtained from base wood. The mean frequencies of sound at high, medium, and low pitch levels are as follows: $248.77 \pm 44.5^{8}, 134.11 \pm$ 12.02 , and $64.77 \pm 8.01 \mathrm{~Hz}$, respectively.

Meanwhile, Table 2 presents the analysis of variance of the talking drums' pitch with respect to sampling height and pitch variation. No significant difference was recorded for sampling height, while a significant difference existed within the pitch variation.

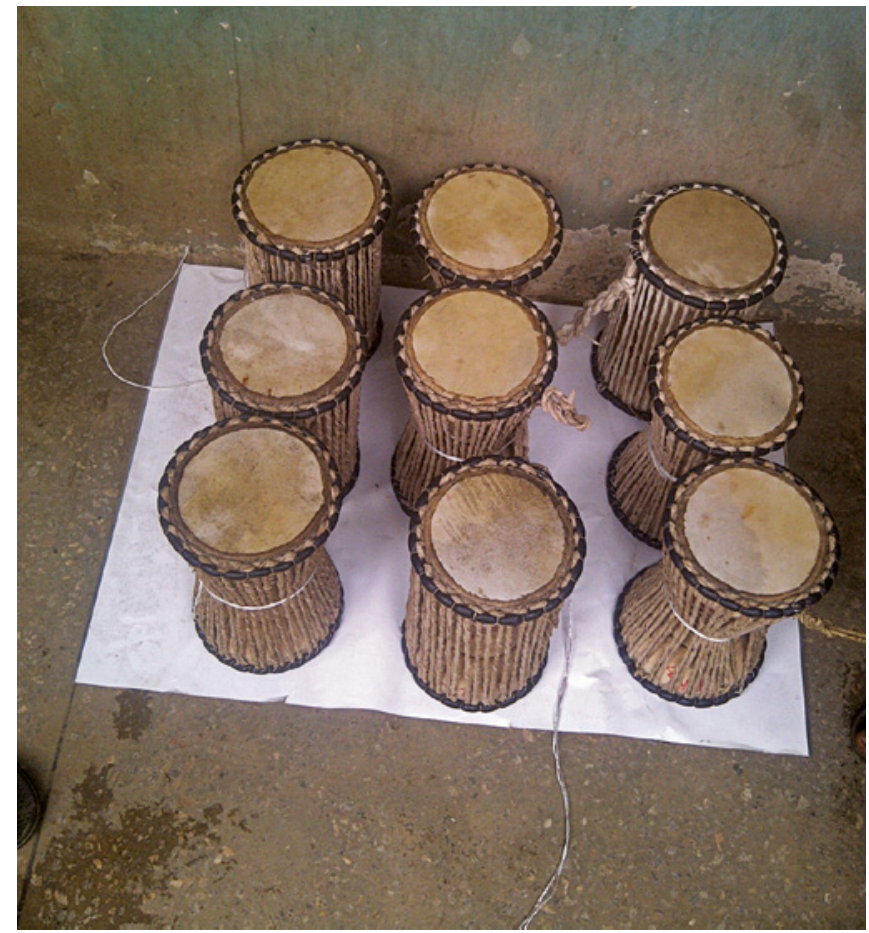

FIGURE 1 Nine manufactured talking drums from the top, middle, and base of Aningeria robusta. 


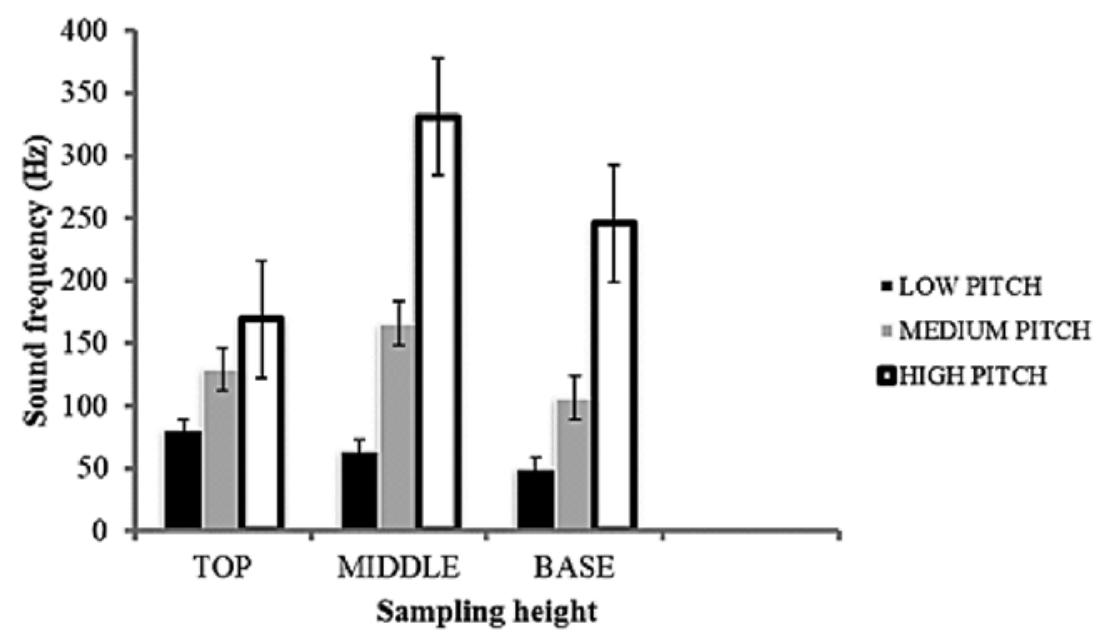

FIGURE 2 Variation in sound frequency $(\mathrm{Hz})$ at different pitch levels in talking drums made from $A$. robusta wood with respect to sampling heights.

TABLE 2 Analysis of variance of the pitch of talking drums made from A. robusta wood with respect to sampling height

\begin{tabular}{lrrrrr} 
Source & $\begin{array}{l}\text { Type III sum } \\
\text { of squares }\end{array}$ & df & Mean square & \multicolumn{1}{l}{ S } & Sig. \\
\hline $\mathrm{SH}$ & 19448.074 & 2 & 9724.037 & 1.560 & 0.237 \\
$\mathrm{SPL}$ & 155235.630 & 2 & 77617.815 & 12.449 & 0.001 * \\
$\mathrm{SH}^{*} \mathrm{SPV}$ & 26582.370 & 4 & 6645.593 & 1.066 & 0.402 \\
Error & 112230.000 & 18 & 6235.000 & &
\end{tabular}

Corrected Total $\quad 313496.074 \quad 26$

SH, sampling height; SPL, sound pitch levels.

* Significant at $5 \%$ probability level.

\subsection{Relationships between Selected Wood Traits and Sound Pitch}

Table 3 shows the respective correlation between wood traits and sound frequency at different pitch levels. The relationships with an existing association of $50 \%$ and above were highlighted, such as impedance and cell wall thickness that had a negative relationship of $50.7 \%$ and $57.6 \%$, respectively, with sound frequency at a low pitch, while fiber diameter had a positive relationship of $54.9 \%$ with high pitch frequency and lumen width had a positive relationship of $57.8 \%$ with low pitch frequency. 
TABLE 3 Correlation analysis between selected wood traits and the pitch of talking drums from A. robusta wood

$F(\mathrm{~Hz})$ at High pitch $F(\mathrm{~Hz})$ at Medium pitch $F(\mathrm{~Hz})$ at Low pitch

\begin{tabular}{lrcc}
\hline Wood density & 0.294 & 0.025 & -0.309 \\
Speed & -0.113 & -0.134 & -0.045 \\
MC & 0.202 & -0.271 & -0.023 \\
MOR & 0.189 & -0.147 & 0.298 \\
Impedance & 0.302 & -0.135 & $-0.507^{*}$ \\
MOE & 0.049 & -0.192 & -0.249 \\
Fiber length & -0.253 & 0.381 & 0.448 \\
Fiber diameter & $0.549^{*}$ & 0.382 & 0.045 \\
Lumen width & -0.024 & 0.060 & $0.578^{*}$ \\
CWT & 0.310 & 0.220 & $-0.576^{*}$ \\
\hline
\end{tabular}

MOR, modulus of rupture; MOE, modulus of elasticity; $F$, frequency of sound.

* Significant at $5 \%$ probability level.

Except for materials such as a tuning fork, every other material that produces sound has more than one sound frequency per hit/strike. The most audible frequency is often used to judge the overall pitch of the sound. This most audible frequency is known as the resonance frequency of the sound. Hence, the sound frequency recorded in this study is known as the resonance sound frequency. As a result, the mean sound frequency obtained for talking drums in this study was higher than what was reported by Noah et al. (2014), who used other wood species to make talking drums. Therefore, it can be assumed that this variation in values of sound frequency is because different wood species were used, highlighting the possibility of a significant relationship between wood traits and the drums' sound frequency. Notwithstanding, adequate analysis is still needed.

Furthermore, it was evident that the frequency obtained from the middle wood of the tree was highest among the sampled tree heights. However, these values were not significantly different among the sampled heights, implying that the major reason for differences in the pitch of the talking drums is not connected to the position of the wood used to make them. Therefore, despite recording the highest sound frequency (at a high pitch) in the middle wood, the pitch of the talking drums manufactured in this study are assumed to be the same. 
Meanwhile, the classification of the values for sound frequency into different pitch levels was significant, hence this study affirms that the pitch of the sound generated from a talking drum can be different depending on the different strikes made while being played.

Notwithstanding, the need to ascertain the influence of the wood used to make these talking drums on the significant variation in pitch levels is pertinent. As such, the relationship between the wood traits and sound frequency of these drums examined in this study revealed that no significant relationship existed. Therefore, this could mean that any wood species can be used for making talking drums without concern about variation in pitch levels.

However, Aiyeloja et al. (2015) stated that wood carvers have preferences for a certain type of wood for making talking drums, thus challenging the findings of this study mentioned above. Consequently, it can be concluded that there are other reasons for wood carvers' and talking drum manufacturers' preferences. These reasons may include the workability of the wood, availability of the wood species, and other acoustic properties of talking drums not examined in this study, among others.

In addition, Stack Exchange (2017) defines frequency as an intrinsic property of a vibrating source that does not depend on the medium through which it travels. Rather, it is a function of its source of propagation. This clearly explains the reason that the correlation analysis between wood traits and frequency in Table 3 had a low to average degree of association. This therefore means that the frequencies generated by the talking drums manufactured from the top, middle, and base wood of $A$. robusta do not depend on any individual wood trait examined in this study, but rather they may be dependent on sources of propagation such as the force of play/strike, tension rope, and skin cover of the talking drum, among others, thus supporting Akere (1995).

Nevertheless, wood traits such as impedance, fiber diameter, lumen width, and cell wall thickness all had a good correlation of $50 \%$ and above with the sound frequency of the talking drums. This implies that the influence of wood traits on the general acoustic properties of talking drums should not be underestimated. Subsequently, more studies should be carried out to determine the causes of wood preference in the manufacture of talking drums.

The decreased impedance value from positive $(+)$ to negative $(-)$ in degree of association from high pitch to low pitch indicates that wood does not restrict lower frequency sounds from passing through it, but tends to reduce higher frequency sounds. This implies that impedance reflects higher pitch sounds than lower pitch sounds, and when a high level of reflection occurs it either results in a constructive or destructive interference of the wave, giving 
rise to high intensity (Berg 2019). Hence, louder sound will be generated. As such, careful consideration should also be given to geometrical shape when making a talking drum.

On the other hand, this study goes against the opinion of Noah et al. (2014), who proposed that the sound frequency obtained from a talking drum is dependent on the MOE of the wood used. Although Ouis (2002) established a relationship between MOE and frequency, the study only revealed a relationship between MOE and the sound frequency of the wood, not the sound frequency of a musical instrument. Apparently, Noah et al. (2014) are mistaken. Thus, relationships such as these should not be confused with each other.

\section{$4 \quad$ Conclusion}

Having successfully established a relationship between wood traits and the sound frequency of talking drums made from A. robusta wood with respect to pitch levels, it can thus be concluded that it is not enough to recommend a wood suitable for manufacturing a talking drum of optimal performance without considering other non-wood factors that can also influence the pitch of the talking drum.

\subsection{Recommendation}

In further studies, careful consideration should be given to sources of sound propagation such as the tension rope, skin surface to be used, and force applied by the player, among others, as these will all determine the pitch of the sound the talking drum will generate.

\section{References}

Abel A.D. 1998. Factors for Aesthetic Evaluation Yoruba Traditional Music. A Journal Polycom 5: 84-85, 89.

Aiyeloja A.A., Adedeji G.A., Adebisi L.A. 2015. Suitability of G. arborea (Roxb.) wood for making talking drum in Nigeria. IOSR Journal of Agriculture and Veterinary Science (IOSR-JAVS) 8(2): 95-100.

Ajala O.O., Ogunsanwo, O.Y. 2011. Specific gravity and mechanical properties of Aningeria robusta wood from Nigeria. Journal of Tropical Forest Science 23(4): 389-395.

Akere A.B. 1995. African Traditional Music. A Journal Polycom 3: 48-50. 
Albert D.J., Clare T.A., Dickson R.L., Walker, J.C.F. 2002. Using acoustics to sort radiata pine pulp logs according to fibre characteristics and paper properties. The International Forestry Review 4(1): 12-14, 16.

American Society for Testing and Materials. 1991. Standard test methods for specific gravity of wood and wood-based materials D2395-02. Annual Book of ASTM Standards 04.10. ASTM International, West Conshohocken, PA.

Berg R.E. 2019. Encyclopcedia Britannica, s.v. "Sound". Encyclopædia Britannica, Chicago, IL. Available online at https://www.britannica.com/science/sound -physics (accessed on August 2019).

Bremaud I. 2012. Acoustical properties of wood in string instruments soundboards and tuned idiophones: Biological and cultural diversity. Journal of the Acoustical Society of America 131(1): 807-818.

Chudnoff M. 1980. Tropical Timbers of the World. Agricultural Handbook No. $6 \circ 7$. USDA Forest Service, Madison, WI.

Femi. 2019. "The Talking Drum: Kalangu, Gangan, and Odondo." Spinditty. HubPages, available online at https://spinditty.com/instruments-gear/The-Talking-Drum-The -Talking-Drum-Kalangu-Gungun-Odondo-drum (accessed September 2019).

Noah A.S., Abiola J.K., Ayeni O.D., Bamidele, O.D. 2014. Comparative assessment of selected acoustic properties of talking drums made from wood of Gmelina arborea (Roxb) and Brachystegia eurycoma (Harms). Journal of Multidisciplinary Engineering Science and Technology (JMEST) 1(5): 22-27.

Okai R. 2003. Characterization of moisture content and specific gravity of branch wood and stem wood of Aningeria robusta and Terminalia ivorensis. Holz als Roh-und Werkstoff 61: $155^{-158 .}$

Olaoye K.O., Ariwoola O.S., Ibiyeye, D.E. 2016. Selected physico-mechanical properties of Aningeria robusta (A.Chev) wood for the manufacture of talking drum. IOSR Journal of Agriculture and Veterinary Science (IOSR-JAVS) 9(2): 57-63.

Ouis D. 2002. Frequency dependence on the modulus of elasticity of wood. Wood Science and Technology 36(6): 335-346.

Plack C.J., Oxenham A.J., Fay, R.R. 2005. Pitch: Neural Coding and Perception. Springer, New York, NY.

Stack Exchange. 2017. Physics - Independence of frequency in sound wave. Stack Exchange, available online at https://physics.stackexchange.com/posts/6oo39/revi sions (accessed September 2019).

Stone R.M. 1998. Music in Africa. In: The Garland Encyclopedia of World Music: 208231. Garland Publishing, New York, NY.

Timber Research and Development Association (TRADA). 1979. Timbers of the World. Publication Construction Press, Lancaster, PA.

Tsoumis G. 1991. Science and Technology of Wood- Structure, Properties, Utilization. Van Nostrand Reinhold, New York, NY. 
Wegst U.G.K. 20o6. Wood for sound. American Journal of Botany 93: 1439-1441.

Wikipedia. 2019. Talking drum. Available online at https://en.wikipedia.org/wiki/ Talking_drum (accessed September 2019).

Yoshikawa S., Waltham, C. 2014. Wood for wooden musical instruments. Proceedings of the International Symposium on Musical Acoustics. ISMA 2014, Le Mans, France; 281-286. 